\title{
CENTRAL PERSONS
}

Bungorō (Ishii)

Chiyo

Daisuke

Fuki

Fumi

Isami

Isoko

Itarō (Ishii)

Jinsuke

Kensuke

Kō

Kōjirō

Kōzō

Masafumi (Ishikawa)

Masako (Matsuura)

Masako (Nakamura)

Mina

Miyo

Moto

Moto
Isami's uncle, a Seiyūkai politician

Isami's daughter-in-law (wife of his first son and heir)

Isami's beloved great-grandfather, eighth-generation Matsuura househead

Isami's third daughter

Isami's fifth daughter

eleventh-generation Matsuura househead

Isami's granddaughter-in-law (wife of Tomoji, thirteenth-generation househead)

Isami's cousin and brother-in-law, consul-general in Shanghai and ambassador to Brazil

Isami's grandfather, ninth-generation Matsuura househead

Isami’s brother

Isami's wife

Isami's second son

Isami's brother

Isami's son-in-law (Toyo's husband)

Isami's daughter-in-law (wife of Yūshirō)

Isami’s granddaughter (Tami’s daughter)

Isami's first daughter

Isami's mother and wife of Yūya, tenth-generation househead

Isami's step-great-grandmother (Daisuke's second wife)

Isami’s sister, wife of Ishii Itarō 
Seishichirō

Shiki

Shinrokurō

Sōtarō (Ishiwata)

Tami

Tatsugorō

Teru

Tomoji

Toshisaburō

Toyo

Yajibei

Yasu

Yatarō

Yōko

Yoshi

Yūshirō

Yūya
Isami's seventh son

Isami's fourth daughter

Isami's sixth son

brother-in-law of Isami's first daughter, Mina, and Imperial Household minister at the end of the Pacific war

Isami's eighth daughter

Isami's fifth son

Isami's sixth daughter

Isami's grandson, thirteenth-generation Matsuura househead

Isami's third son

Isami's second daughter

founding ancestor of the Matsuura lineage

Isami's seventh daughter

Isami's first son and heir, twelfth-generation

Matsuura househead

Isami's granddaughter (Toyo's daughter)

Isami's grandmother, wife of ninth-generation househead, Jinsuke

Isami's fourth son

Isami's father, tenth-generation Matsuura

househead 



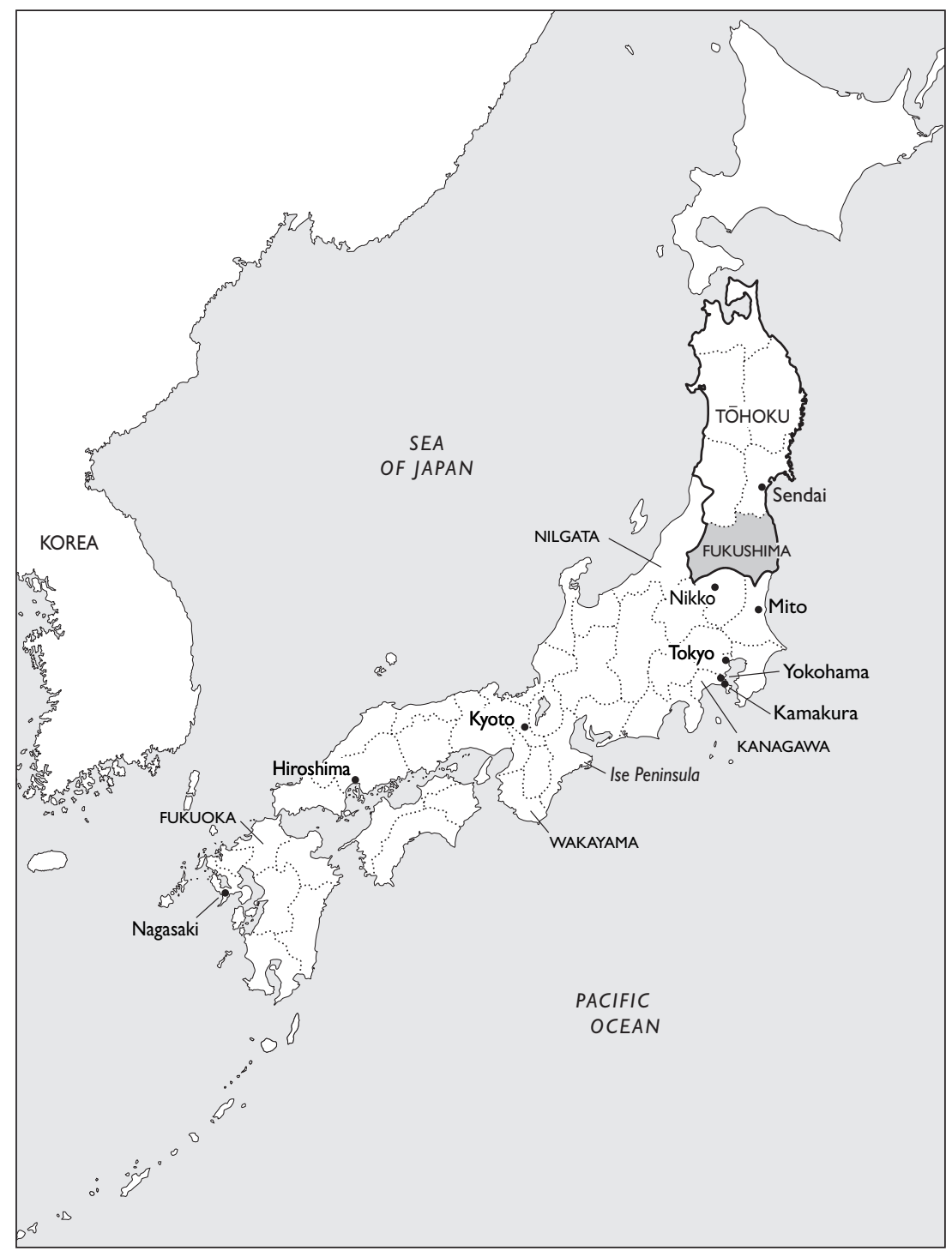

MaP I Modern Japan 